\section{Characterization of phase transformation and thermal behavior of Sedlecky Kaolin}

EMESE KUROVICS - Institute of Ceramics and Polymer Engineering, University of Miskolc, Hungary - fememese@uni-miskolc.hu

OLGA B. KOTOVA - Institute of Geology, Komi Science Center, Ural Branch of the Russian Academy of Sciences, Russian Federation • kotova@geo.komisc.ru

JAMAL ELDIN F. M. IBRAHIM - Institute of Ceramics and Polymer Engineering, University of Miskolc, Hungary • jamalfadoul@gmail.com

Монамmed TIHTIH - Institute of Ceramics and Polymer Engineering, University of Miskolc, Hungary • medtihtih@gmail.com

SHIYoNG SUN - Key Laboratory of Solid Waste Treatment and

Resource Recycle of Ministry of Education, School of Environment and Resource, Southwest University of Science and Technology, China - shysun@swust.edu.cn

PÉTER PALA - Refratechnik Hungaria Ltd, Hungary

LÁszLó A. GÖMZE - Institute of Ceramics and Polymer Engineering,

University of Miskolc, Hungary, IGREX Engineering Service Ltd. • femgomze@uni-miskolc.hu

Érkezett: 2020. 06. 30. - Received: 30. 06. 2020. • https://doi.org/10.14382/epitoanyag-jsbcm.2020.24

\section{Abstract}

The authors have examined how the properties are changing using different sintering temperature based on the kaolin. Kaolin powder and a mixture of kaolin and $10 \mathrm{~m} \%$ alumina was made and measured their sintering properties (TG, DTG, DTA, height). Pellets were compacted from the powders and sintered at $450{ }^{\circ} \mathrm{C}, 575{ }^{\circ} \mathrm{C}, 775^{\circ} \mathrm{C}, 870{ }^{\circ} \mathrm{C}, 1100{ }^{\circ} \mathrm{C}$ temperature. The volume shrinkage, sintering weight losses, microstructure and phase composition of sintered specimens were investigated. In the case of sintering at $450{ }^{\circ} \mathrm{C}$ the volume of the samples increased; with a further increase of the temperature a continuous volume decrease can be observed.

Keywords: alumina, derivatograph, kaolin, mullite, XRD

Kulcsszavak: alumínium-oxid, derivatográf, kaolin, mullit, XRD

\section{Introduction}

In the case of ceramics, the used drying and sintering methods greatly influences the properties of the product [1-7], so it is important to know the effect of sintering temperature. Because of this both in the traditional and in the technical ceramic industry there are a significant role of selected temperature and the condition (atmosphere) of the heat treatment [8-13]. The heat treatment affects the composition, physical, mechanical and functional properties of the product [10-18]. The phase diagrams can help to plan the composition of the final product from the raw materials. Even the simple materials systems like $\mathrm{Al}_{2} \mathrm{O}_{3}-\mathrm{SiO}_{2}$ also has been studied by many researchers. Two phase diagrams of $\mathrm{Al}_{2} \mathrm{O}_{3}-\mathrm{SiO}_{2}$ system are shown in Fig. 1 [19-20]. The alumina-hydro-silicates such as the conventional kaolinite can also study partly with these phase diagrams, because they can show their thermal decomposition [21-22]. Many studies can be read regarding to the thermal properties of kaolin [23-26] and its kinetic analysis [27-28]. Kaolin and other clay minerals are usually raw materials obtained from nature which are widely used in the ceramic industry [29-32]. These materials may contain several contaminants and oxides, which may change the phases formed during heat treatment and their amount compared to what is theoretically expected.

In this research the authors have examined how the Sedlecky $\mathrm{ml}$ kaolin and alumina powder mixture behave under heating using a derivatograph and a heating microscope [33]. From
Emese KUROVICS

is graduated from the University of Miskolc, Department of Ceramics and Silicate Engineering as a material engineer, where she continues her study as PhD student under supervision of Prof L. A. Gömze.

Olga В. KOTOVA

is professor and Head of Laboratory of Technology of Mineral Raw, Institute of Geology, Komi Science Center, Ural Branch of the Russian Academy of Sciences. Author and co-author of 4 patents and more than 150 scientific articles. Vice-president of International Commission on Applied Mineralogy (IMA-ICAM). Member of Russian Mineralogical Society.

Jamal Eldin F. M. IBRAHIM is a lecturer in the University of Bahri, Khartoum, Sudan, he graduated from University of Marmara, Istanbul, Turkey, Institute of Pure and Applied Sciences, Department of Metallurgical and Materials Engineering, for the time being, he is a PhD student in the University of Miskolc, Institute of Polymer and Ceramics Engineering, under supervision of Prof. L. A. Gömze.

Mohammed TIHTIH Is a lecturer in the Sidi Mohamed Ben abdellah University, Morocco, he graduated from Faculty of sciences Dhar El Mahraz, Fez, Morocco, Department of Physics, for the time being, he is a PhD student in the University of Miskolc, Institute of Ceramics and Polymer Engineering, under supervision of Prof. L. A. Gömze

Péter PALA

Is a chemical engineer who finished his study at the University of Pannonia. He has been working in the ceramics industry since 2003 , at present he is the managing director of Refratechnik Hungaria Ltd.

László A. GöMZE is establisher and professor of the Department of Ceramics and Silicate Engineering in the University of Miskolc, Hungary. He is author or co-author of 2 patents, 6 books and more than 300 scientific papers.

the powder mixture ceramic specimens were also made to determine how the volume, weight and phases are changing using different sintering temperatures.

\section{Materials and experiments}

For the tests, kaolin and a mixture of kaolin and $10 \mathrm{~m} \%$ alumina was milled in Retsch PM 400 planetary ball mill for $20 \mathrm{~min}$ at $150 \mathrm{rpm}$. The sintering behavior of powders were measured with a Camar Elettronica heating microscope and a MOM Derivatograph-C. During the tests, the furnaces were heated up to $1200^{\circ} \mathrm{C}$ at a heating rate of $12^{\circ} \mathrm{C} / \mathrm{min}$. The heating microscope took photos every $5^{\circ} \mathrm{C}$.

Specimens were made from the mixtures with uniaxially pressing method using a $100 \mathrm{kN}$ mechanical pull-press machine. The pressed specimens were sintered in an electrical chamber kiln using different maximum kiln temperature and were kept at this temperature for 3 hours (Fig. 2).

The maximum temperature for sintering was chosen based on the $\mathrm{SiO}_{2}-\mathrm{Al}_{2} \mathrm{O}_{3}$ phase diagram [20], waiting for the following phase transitions: $450{ }^{\circ} \mathrm{C}$ - kaolinite-metakaolinite; 

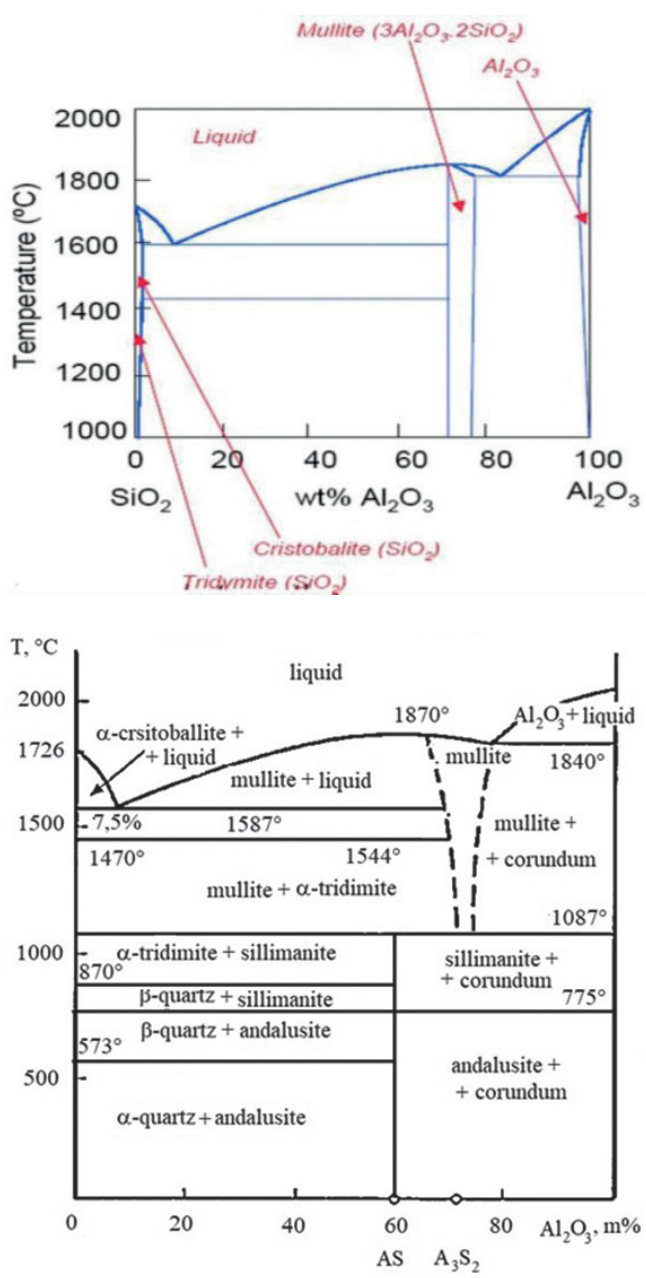

1. ábra $\mathrm{SiO}_{2}-\mathrm{Al}_{2} \mathrm{O}_{3}$ rendszer normál körülmények között (átvéve L. Gömze A., 2001 [16] N M Bobkova 2007 [17])

Fig. $1 \mathrm{SiO}_{2}-\mathrm{Al}_{2} \mathrm{O}_{3}$ system at normal (Taken from L. A. Gömze, 2001 [19] N M Bobkova 2007 [20])

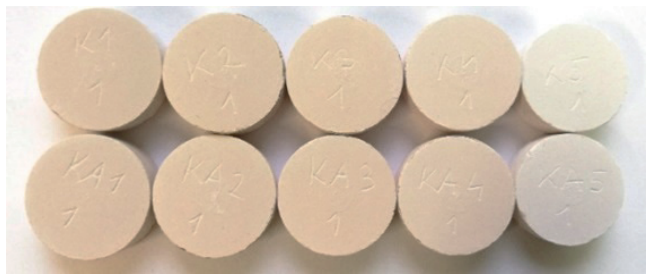

2. ábra A $450^{\circ} \mathrm{C}, 575^{\circ} \mathrm{C}, 775^{\circ} \mathrm{C}, 870^{\circ} \mathrm{C}$ és $1100^{\circ} \mathrm{C}$ hömérsékleten szinterelt minták Fig. 2 The specimens sintered at $450{ }^{\circ} \mathrm{C}, 575{ }^{\circ} \mathrm{C}, 775{ }^{\circ} \mathrm{C}, 870{ }^{\circ} \mathrm{C}, 1100{ }^{\circ} \mathrm{C}$ temperature

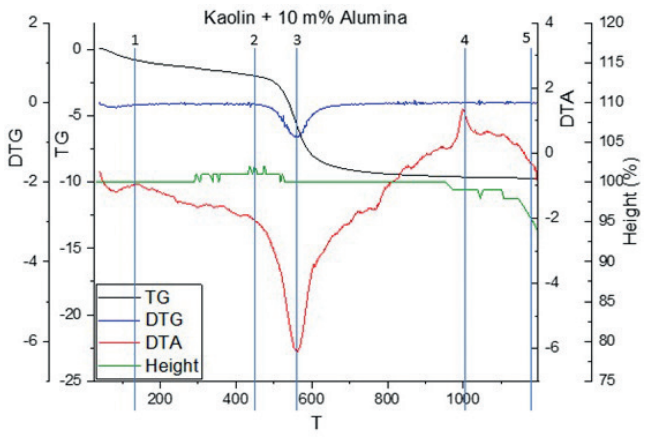

3. ábra Kaolin és alumínium-oxid keverék termoanalitikai görbéi Fig. 3 Thermo-analytical curves of kaolin and alumina mixture
$575{ }^{\circ} \mathrm{C}$ - $\alpha$-quartz- $\beta$-quartz; $775^{\circ} \mathrm{C}$ - andalusite-sillimanite; $870^{\circ} \mathrm{C}$ - $\beta$-quartz-tridymite; $1100^{\circ} \mathrm{C}$ - metakaolinite-mullite transitions. As the sintering temperature increases, the color of the specimens changes continuously. When the sintering temperature achieved $1100{ }^{\circ} \mathrm{C}$ the specimens became white. The change in color may indicate that the expected phase transitions have occurred. The properties of sintered specimens were measured, like volume shrinkage, sintering weight losses, microstructure, phase composition. The microstructures were examined by Hitachi TM-1000 scanning electron microscopy and XRD pattern were recorded with a Rigaku MiniFlex II $\mathrm{X}$-ray diffractometer.

\section{Results and discussions}

The results of the thermo-analytical test of the kaolinalumina mixture are shown in Fig. 3. From the achieved curves can be distinguish between drying 1 , thermal degradation of kaolin 2-3 (conversion to metakaolin), formation of mullite 4 and sintering point 5 (where by the Camar Electronic the height of the sample compared to the original is 95\%).

Sintering at $450{ }^{\circ} \mathrm{C}$ increases the volume of specimens while decreasing their mass. At $575^{\circ} \mathrm{C}$, a weight loss of more than $10 \%$ is observed, which is because of the kaolinite-metakaolinite conversion is complete. The kaolinite mineralloses its crystalline water content (kaolinite mineral composition: $39.52 \mathrm{~m} \% \mathrm{Al}_{2} \mathrm{O}_{3}$, $46.52 \mathrm{~m} \% \mathrm{SiO}_{2}, 13.96 \mathrm{~m} \% \mathrm{H}_{2} \mathrm{O}$ ). The change in mass from $575^{\circ} \mathrm{C}$ was already slightly influenced by the added $\mathrm{Al}_{2} \mathrm{O}_{3}$ content. The initial volume of specimens and the volume of specimens sintered at $1250^{\circ} \mathrm{C}$ were approximately the same for both mixtures (Fig. 4).

Some fracture samples were taken from the sintered specimens to examine the microstructure changes depending on the used maximum temperature. The fracture surface of the KA samples can be seen in the Fig. 5 where the characteristics structure of the clay minerals and the added fine-grained alumina are well observable.

The mineral composition was not significantly affected by the addition of $\mathrm{Al}_{2} \mathrm{O}_{3}$ and is present throughout the corundum phase in the samples due to the low sintering temperatures. The XRD pattern shown in the Fig. 6 . The mineral composition of the samples from the used kaolin sintered at $450{ }^{\circ} \mathrm{C}$ contain a-quartz and clay minerals like kaolinite and muscovite. In the experiment as the sintering temperature increased, the phase transitions took place as expected. Thus, the XRD pattern of the samples prepared during the research confirm the $\mathrm{Al}_{2} \mathrm{O}_{3}$ $\mathrm{SiO}_{2}$ phase diagram found in Bobkova's book [20]. During the sintering at $1100^{\circ} \mathrm{C}$, the mullite phase was formed (Table 1). The proportion of crystalline phase is higher due to the addition of $\mathrm{Al}_{2} \mathrm{O}_{3}$ in the KA mixture. The ratio of mullite to tridymite was the same for both mixtures (mullite/tridymite $~ 10.6$ ). 


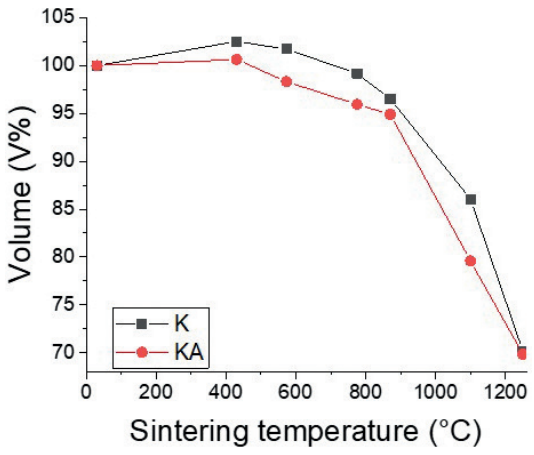

a)

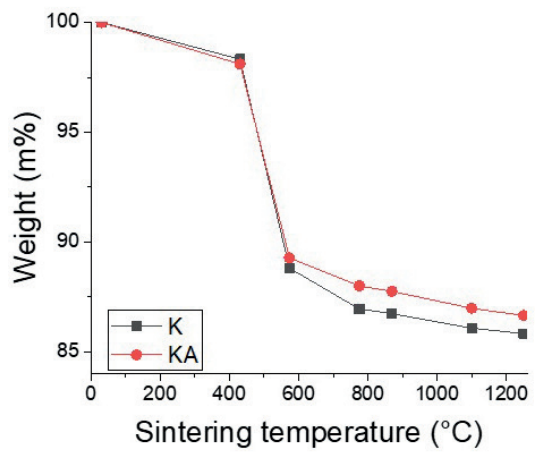

b)

4. ábra $A z$ (a) térfogat és a (b) tömeg változása különböző hömérsékleten

Fig. 4 The changing of volume (a) and weight (b) using different temperature

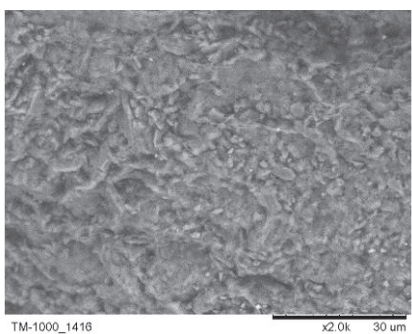

$450{ }^{\circ} \mathrm{C}$

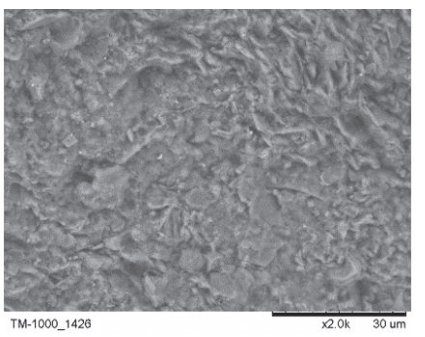

$775^{\circ} \mathrm{C}$

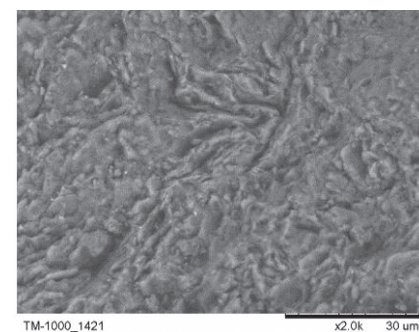

$575^{\circ} \mathrm{C}$

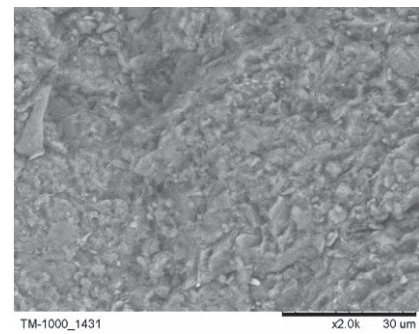

$870{ }^{\circ} \mathrm{C}$



$1100^{\circ} \mathrm{C}$

5. ábra A különbözö hömérsékleten szinterelt KA minták töretfelületének mikroszerkezete

Fig. 5 The microstructure of the fracture surface of the KA specimens sintered at different temperature
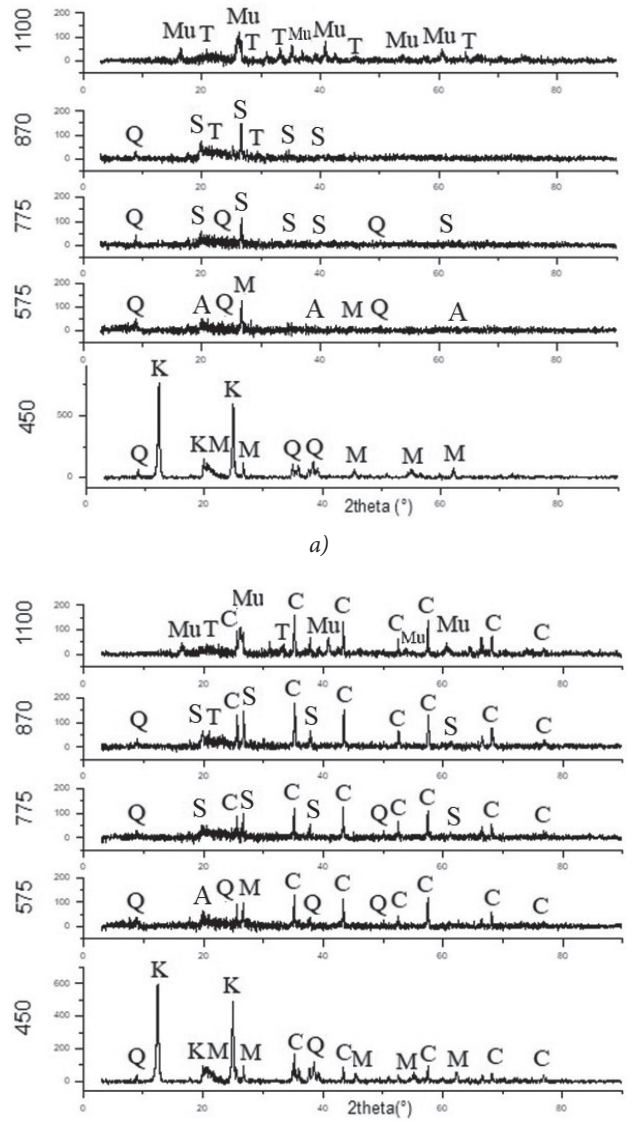

b)

6. ábra AK (a) és KA (b) minta XRD mintája különböző szinterezési hömérsékleten (A-andalúzit, C-korund, K-kaolinit, M-muszkovit, Mu-mullit, S-szillimanit, T-tridimit, Q-kvarc)

Fig. 6 The XRD pattern for sample $K(a)$ and $K A(b)$ at different sintering temperature. (A-andalusite, C-corundum, K-kaolinite, M-muscovite, Mu-mullite, S-sillimanite, T-tridymite, Q-quartz)

\begin{tabular}{cccc}
\multicolumn{2}{c}{ Sign of the mixture } & K & KA \\
Phase content, $\mathbf{m} \%$ & Amorph & 61.4 & 47 \\
\cline { 2 - 4 } & Crystalline & 38.6 & 53 \\
\cline { 2 - 4 } & mullite & 91.45 & 63.13 \\
\hline tridymite & 8.55 & 5.97 \\
\cline { 2 - 4 } & corundum & - & 30.9
\end{tabular}

1. táblázat $1100^{\circ} \mathrm{C}$-on szinterelt minták fázisaránya

Table 1 Phase ratio for samples sintered at $1100^{\circ} \mathrm{C}$

\section{Conclusions}

In this research work the Sedlecky ml kaolin as a traditional ceramic raw material were studied. The authors investigated how the microstructure, the phase composition changes depending on the used sintering temperature and how they will be changing when a small amount $(10 \mathrm{~m} \%)$ alumina were added to the kaolin raw mineral. From the experiments of derivatograph and heating microscopy investigation it can be concluded that both kaolin $(\mathrm{K})$ and mixed (KA) powders shown the characteristic thermal curve of kaolin. The SEM and XRD results of the sintered specimens also confirm that $10 \mathrm{~m} \%$ alumina has no significant effect on the sintering properties compering the pure kaolin when low sintering temperatures are used but it can be seen that at $1100{ }^{\circ} \mathrm{C}$ the proportion of crystalline fraction is significantly higher in the case of the alumina-containing mixture due to 
the corundum phase. The added alumina affects the functional properties of the ceramic products.

\section{Acknowledgements}

The described article was carried out as part of the EFOP3.6.1-16-00011 "Younger and Renewing University Innovative Knowledge City - institutional development of the University of Miskolc aiming at intelligent specialisation" project implemented in the framework of the Széchenyi 2020 program. The realization of this project is supported by the European Union, co-financed by the European Social Fund.

\section{References}

[1] L. A. Gömze, L. N. Gömze (2008): Relations between the material structures and drying properties of ceramic bricks and roof tiles, Építőanyag-JSBCM. Vol. 60. No.4. p.102 http://dx.doi.org/10.14382/epitoanyag-jsbcm.2008.16

[2] Kulkov S. N., Grigoriev. M. V. (2010): Sintering of $\mathrm{Al}_{2} \mathrm{O}_{3}$ ceramics based on different sizes powders. Építőanyag-JSBCM. Vol. 62. No.3. pp.66-69. http://dx.doi.org/10.14382/epitoanyag-jsbcm.2010.13

[3] Kurovics E., Buzimov A. Y., Gömze A. L. (2016): Influence of raw materials composition on firing shrinkage, porosity, heat conductivity and microstructure of ceramic tiles. IOP Conf. Ser.: Mater. Sci. Eng. Vol. 123. 012058 https://doi.org/10.1088/1757-899X/123/1/012058

[4] Ibrahim J. E. F. M., Gömze A. L., Kotova O. B., Shchemelinina T. N., Shushkov D. A., Ignatiev G. V., Anchugova E. M. (2019): The influence of composition, microstructure and firing temperature on the density, porosity, and shrinkage of new zeolite-alumina composite material. Építőanyag - JSBCM Vol. 71. No.4 pp. 120-124. https://doi.org/10.14382/epitoanyag-jsbcm.2019.21

[5] Kurovics E., Kulkov S. N., Gömze A. L. (2018): Investigation of ceramic brick rods with blackened materials inside. Építőanyag-JSBCM Vol. 70. No.1. p. 3 https://doi.org/10.14382/epitoanyag-jsbcm.2018.1

[6] J. F. M. Ibrahim, E. Kurovics, M. Tihtih, P. Somdee, A. G. Gerezgiher, K Nuilek E. E. Khine and M. Sassi (2020): Preparation and Investigation of Alumina-Zeolite Composite Materials. J. Phys.: Conf. Ser. Vol. 1527, 012029 https://doi.org/10.1088/1742-6596/1527/1/012029

[7] T. S. Aarnæs, M. Tangstad, (2019): Effect of $\mathrm{H}_{2}$ on $\mathrm{SiO}$ and $\mathrm{SiC}$ formation, Építőanyag - JSBCM Vol. 71, No. 6, 194-197.p. https://doi.org/10.14382/epitoanyag-jsbcm.2019.34

[8] M. M. Abdelfattah, I. Kocserha, R. Géber (2019): The effect of calcium fluoride on mineral phases and properties of lightweight expanded clay aggregates. XIIIth Preparation of Ceramic Materials p. 141 ISBN: 978-80-553-3314-4

[9] E. Kurovics, B. Udvardi, K. Román, J. E. F. M. Ibrahim, L. A. Gömze (2019): Examination of the carbonization process using kaolin and sawdust. WIT Transactions on Engineering Sciences Vol. 124 p. 17 https://doi.org/10.2495/MC190021

[10] E. Kurovics, O. B. Kotova, L. A. Gömze, D A Shushkov, G. V. Ignatiev, P. A. Sitnikov, Y. I. Ryabkov, I. N. Vaseneva, L. N. Gömze (2019): Preparation of particle-reinforced mullite composite ceramic materials using kaolin and IG-017 bio-origin additives. Építőanyag - JSBCM Vol. 71 No. 4 p. 114 https://doi.org/10.14382/epitoanyag-jsbcm.2019.20

[11] Khare, S., Sharma, M., Venkateswarlu, K. (2010): Effect of scandium additions on pressure less sintering of Al-TiN metal matrix composites. Építőanyag, Vol. 61. No.2. pp. 39-42. http://dx.doi.org//10.14382/epitoanyag-jsbcm.2010.8

[12] Tamásné Csányi Judit, Gömze A. László (2008): Impact of nitrogen atmosphere on sintering of alumina ceramics. Építőanyag - JSBCM Vol. 60. No.1 p. 15 http://dx.doi.org/10.14382/epitoanyag-jsbcm.2008.4

[13] Kulkov, S. N., Dedova, E. S., Pedraza, F., Erdélyi, J. (2014): Porosity and Mechanical Properties of Zirconium Ceramics. Építőanyag - JSBCM, Vol. 66, No. 2 pp. 35-37. http://dx.doi.org/10.14382/epitoanyag-jsbcm.2014.7

[14] Zhengwei Nie, Yuyi Lin (2015): Fabrication of porous alumina ceramics with corn starch in an easy and low-cost way, Ceramics Silikaty Vol. 59 No.4 pp. 348-352

[15] K. Ornam, M. Kimsan, E. Cahyono (2015): Evaluation of alternative desing of hollow brick with sawdust as filler for home-made industry, Advances in Environmental and Agricultural Science, Vol. 32, pp.373-376 ISBN: 978-1-61804-270-5

[16] Zhibin Ma, Chaolu Wen, Kezhou Yan, Yanxia Guo, Fangqin Cheng (2019): Effects of reducing environment and fusible components on carbothermal reduction-nitridation reaction of coal gangue at high temperature under $\mathrm{N}_{2}$ atmosphere, Ceramics International, Vol. 45, Issue 17, Part B, pp. 22829-22840, https://doi.org/10.1016/j.ceramint.2019.07.325

[17] M. N. Ismael, H. F. Hassan, H. S. Al-lami (2020): Effect of silica particle size on the physical and mechanical properties of lightweight ceramic composites, Revista de Chimie, Vol. 71. No. 5, pp. 65-74, https://doi.org/10.37358/RC.20.5.8114

[18] E. Kurovics, J. F. M. Ibrahim, M. Tihtih, B. Udvardi, K. Nuilek and L. A. Gömze (2020): Examination of mullite ceramic specimens made by conventional casting method from kaolin and sawdust, J. Phys.: Conf. Ser. Vol. 1527012034 https://doi.org/10.1088/1742-6596/1527/1/012034

[19] L. A. Gömze, Á. Liszátzné Helvei, A. Simonné Odler, M. Szabó (2001): Ceramic yearbook I. 2001, ÉTK and MÉASZ, Budapest, ISBN 963512774 X pp.30-85

[20] Bobkova N. M. (2007): Fizicheskaya Himiya Tugoplavkih Nemetallicheskihi Silicatnyh Materialov, Yvyshej Shaya, Minszk, P. 88-90 ISBN 978-985-06-1389-9

[21] G Varga (2007): The structure of kaolinite and metakaolinite. Építőanyag, Vol. 59, No.1 p. 6 http://dx.doi.org/10.14382/epitoanyag-jsbcm.2007.2

[22] A Borosnyói, A. Szijártó (2016): Metakaolin vizsgálata cement kiegészítô anyagként a k-érték elve szerint. Építőanyag - JSBCM Vol. 68, No. 2 p. 40 http://dx.doi.org/10.14382/epitoanyag-jsbcm.2016.7

[23] G. Kakali, T. Perraki, S. Tsivilis, E. Badogiannis(2001): Thermal treatment of kaolin: the effect of mineralogy on the pozzolanic activity, Applied Clay Science, Vol. 20. No.1-2 pp. 73-80 https://doi.org/10.1016/S0169-1317(01)00040-0

[24] Wang, H., Li, C., Peng, Z. et al. (2011): Characterization and thermal behavior of kaolin. Journal of Thermal Analysis and Calorimetry Vol. 105. pp.157-160 https://doi.org/10.1007/s10973-011-1385-0

[25] F. Sahnoune, M. Chegaar, N. Saheb, P. Goeuriot, F. Valdivieso (2013): Differential thermal analysis of mullite formation from Algerian kaolin, Advances in Applied Ceramics, Structural, Functional and Bioceramics, Vol. 107 pp. 9-13 https://doi.org/10.1179/174367607X228007

[26] O. Castelein, B. Soulestin, J. P. Bonnet, P. Blanchar (2001): The influence of heating rate on the thermal behaviour and mullite formation from a kaolin raw material, Ceramics International, Vol. 27. No.5 pp. 517-522 https://doi.org/10.1016/S0272-8842(00)00110-3

[27] Petr Ptáček, Dana Kubátová, Jaromír Havlica, Jiří Brandštetr, František Šoukal, Tomáš Opravil (2010): Isothermal kinetic analysis of the thermal decomposition of kaolinite: The thermogravimetric study, Thermochimica Acta, Vol. 501. No.1-2 pp. 24-29 https://doi.org/10.1016/j.tca.2009.12.018

[28] Tomáš Ondro, Omar Al-Shantir, Štefan Csáki, František Lukáč, Anton Trník (2019): Kinetic analysis of sinter-crystallization of mullite and cristobalite from kaolinite, Thermochimica Acta Vol. 678. p. 178312 https://doi.org/10.1016/j.tca.2019.178312

[29] L A Gömze, S N Kulkov, E Kurovics, A S Buyakov, S P Buyakova, A Y Buzimov, R Géber, M V Grigoriev, I Kocserha, A S Kulkov, T Yu Sablina, N L Savchenko, I N Sevostyanova, A Simon (2018): Investigation of mineralogical composition and technological properties of conventional brick clays. Építőanyag - JSBCM Vol. 70. No.1 p. 8 https://doi.org/10.14382/epitoanyag-jsbcm.2018.2

[30] O Kotova (2013): Clay Minerals: Adsorbophysical Properties. IOP Conf. Ser.: Mater. Sci. Eng. Vol.47 012037 https://doi.org/10.1088/1757-899X/47/1/012037

[31] Š Csáki, I Štubňa, V Trnovcová, J Ondruška, L Vozár and P Dobroň (2017): Evolution of AC conductivity of wet illitic clay during drying. IOP Conf. Ser.: Mater. Sci. Eng.Vol. 175012041 https://doi.org/10.1088/1757-899X/175/1/012041

[32] Alexandra Hamza and István Kocserha (2020): The effect of expanded perlite on fired clay bricks. J. Phys.: Conf. Ser. Vol. 1527, 012032 https://doi.org/10.1088/1742-6596/1527/1/012032

[33] Kurovics E., Gömze A. L. (2019): Thermo-analytical analysis of kaolin and bio-additive mixtures using a derivatograph and heating microscope. Preparation of Ceramic Materials Proceedings of Edited Contributions, p. 180 ISBN: 978-80-553-3314-4

\section{$\underline{\text { Ref.: }}$}

Kurovics, Emese - Kotova, Olga B. - Ibrahim, Jamal Eldin F. M. - Tihtih, Mohammed - Sun, Shiyong - Pala, Péter - Gömze, László A.: Characterization of phase transformation and thermal behavior of Sedlecky Kaolin Építőanyag - Journal of Silicate Based and Composite Materials, Vol. 72, No. 4 (2020), 144-147. p. https://doi.org/10.14382/epitoanyag-jsbcm.2020.24 